\title{
Multimedia Interaktif \\ Pembelajaran Bahasa Arab Untuk Siswa Madrasah Aliyah
}

\author{
Renti Yasmar \\ Sekolah Tinggi Agama Islam Negeri (STAIN) Curup \\ inga_y@yahoo.com
}

\begin{abstract}
Abstrak
Penelitian ini bertujuan untuk menghasilkan Media Pembelajaran bahasa Arab yang layak untuk siswa Madrasah Aliyah dilihat dari hasil validasi ahli materi, ahli media dan respon guru serta siswa terhadap CD Interaktif Pembelajaran Bahasa Arab yang dikembangkan. Penelitian ini dilatarbelkaangi oleh minimnya media pembelajaran bahasa arab di Madrasah Aliyah Muhammadiyah Yogyakarta sehingga guru mersa kesulitan di dalm menjelaskan materi-materi bahasa Arab Jenis penelitian ini adalah penelitian dan pengembangan dengan tahapan yang terdiri dari (1) analisis kebutuhan, (2) desain pembelajaran (3) pengembangan produk, (4) Validasi (5) Penilaian produk dari guru dan siswa, (6) Produk Akhir. Proses validasi dilakukan oleh 1 orang ahli media dan 1 orang ahli materi. Subjek penelitian adalah guru Bahasa Arab Madrasah Mu'allimaat Muhammadiyah Yogyakarta tingkat Aliyah berjumlah 2 orang dan siswa Madrasah Mu'allimaat Muhammadiyah Yogyakarta berjumlah 30 siswa. Data diperoleh menggunakan angket untuk ahli media dan ahli materi serta tanggapan atau respon siswa terhadap media yang dikembangkan pada aspek pembelajaran, aspek materi, aspek tampilan dan aspek pemrograman. Data dianalisis dengan analisis deskriptif kuantitatif. Hasil penelitian menunjukkan bahwa penilaian ahli materi terhadap kelayakan CD Interaktif Pembelajaran Bahasa Arab dari aspek pembelajaran dengan rerata 4,17 (baik) dan aspek materi dengan rerata 4,00 (baik). Penilaian ahli media terhadap kelayakan CD Interaktif Pembelajaran Bahasa Arab dari aspek tampilan dengan rerata 4,15 (baik) dan aspek pemrograman dengan rerata 4,00 (baik). Hasil respon guru terhadap CD Interaktif Pembelajaran bahasa Arab menunjukkan bahwa guru memberikan respon positif terhadap CD Interaktif Pembelajaran Bahasa Arab dilihat dari aspek pembelajaran dengan rerata 4,12 (baik), aspek materi dengan rerata 4,16 (baik), aspek tampilan dengan rerata 4,19 (baik), dan aspek pemrograman dengan rerata 4,21 (baik). Hasil tanggapan atau respon siswa terhadap CD Interaktif Pembelajaran bahasa Arab menunjukkan bahwa siswa memberikan respon positif terhadap CD
\end{abstract}

Arabiyatuna : Jurnal Bahasa Arab, Vol. 1, No. 2, 2017

STAIN Curup | ISSN 2580-5053 (e), 2580-5045 (p)

Available online: http://journal.staincurup.ac.id/index.php/arabiyatuna 
Interaktif Pembelajaran Bahasa Arab dilihat dari aspek pembelajaran dengan rerata 4,12 (baik), aspek materi dengan rerata 4,10 (baik), aspek tampilan dengan rerata 4,07 (baik), dan aspek pemrograman dengan rerata 4,12 (baik). Hasil penelitian ini menyimpulkan bahwa CD Interaktif pembelajaran bahasa Arab yang dikembangkan layak digunakan untuk siswa Madrasah Aliyah Kata Kunci: Pengembangan, Pembelajaran Bahasa Arab, Tingkat Aliyah

\begin{abstract}
This study aims to produce appropriate Arabic Learning Media for Madrasah Aliyah students viewed from the validation results of material experts, media experts and teacher and student responses to the developed Arabic Learning Interactive CD. This research is based on the lack of Arabic language learning media in Madrasah Aliyah Muhammadiyah Yogyakarta so that the teacher difficulties in dalm explain Arabic materials. This research type is research and development with stages consist of (1) needs analysis, (2) instructional design 3) product development, (4) Validation (5) Product assessment of teachers and students, (6) Final Product. The validation process is done by 1 media expert and 1 material expert. The subjects of the study were the teachers of Arabic Madrasah Mu'allimaat Muhammadiyah Yogyakarta at the level of Aliyah amounting to 2 people and the students of Madrasah Mu'allimaat Muhammadiyah Yogyakarta amounted to 30 students. The data were obtained using questionnaires for media experts and material experts as well as students' responses or responses to media developed on the aspects of learning, material aspects, display aspects and programming aspects. Data were analyzed by quantitative descriptive analysis. The result of the research shows that the material expert judgment on the feasibility of Interactive $\mathrm{CD}$ of Arabic Learning from the learning aspect with the average 4,17 (good) and the material aspect with the average 4,00 (good). Assessment of media expert on the feasibility of Interactive CD of Arabic Learning from aspect of display with average 4,15 (good) and programming aspect with average 4,00 (good). Teachers' responses to Interactive CDs Arabic learning shows that teachers give positive responses to Interactive CD of Arabic Learning seen from learning aspect with average 4,12 (good), material aspect with average 4,16 (good), aspect of display with average 4, 19 (good), and programming aspect with average 4,21 (good). The result of responses or students' responses to Interactive CDs The learning of Arabic shows that students give positive responses to Interactive CD of Arabic Learning seen from learning aspect with average 4,12 (good), material aspect with average of 4.10 (good), aspect of display average 4,07 (good), and programming aspect with a mean
\end{abstract}


of 4.12 (good). The results of this study conclude that the Interactive $\mathrm{CD}$ of learning Arabic language developed feasible to be used for Madrasah Aliyah students

Keywords: Development, Learning Arabic, Aliyah Level

\section{Pendahuluan}

Salah satu upaya peningkatan mutu dalam proses belajar mengajar khususnya pembelajaran bahasa Arab dengan indikator keberhasilan pembaharuan kurikulum ditunjukkan dengan adanya perubahan pada pola kegiatan pembelajaran. Sistem pembelajaran bahasa Arab di Indonesia sebagaimana dikemukakan Busyairi Madjidi bahwa sebelum diberlakukannya kurikulum 1976 untuk madrasah-madrasah dalam lingkungan Departemen Agama diselenggarakan dengan sistem tradisional (furu'yah). ${ }^{1}$ Pembelajaran bahasa Arab dengan sistem ini terbagi menjadi beberapa mata pelajaran yaitu; nahwu, sharaf, qir $>$ oah, insya', muha $>$ das $\mid a h$, dan masing-masing berdiri sendiri dengan buku dan jam tersendiri. Akan tetapi, sistem ini terdapat kelemahan karena dalam proses belajar mengajar menimbulkan ketidakseimbangan dalam pertumbuhan bahasa yang menjadi penyebab kelemahan perkembangan bahasa siswa

Sistem pembelajaran tradisional (fur ' $y a b)$ ini kemudian dirubah menjadi sistem naz\}ariat wabdah (all in one system atau teori kesatuan) yang diperkenalkan oleh Abu Abbas al-Mubarrak. Sistem ini dalam kesusastraan klasik Islam memandang bahasa sebagai satu kesatuan yang utuh dan alat komunikasi yang saling berhubungan, dan memuat semua mata pelajaran dalam satu kerangka terpadu yaitu dimulai dengan wacana bacaan, percakapan, latihan gramatik, dan menulis.

Mempelajari bahasa Arab sebagaimana mempelajari bahasa asing lainnya tentulah terdapat kesulitan. Kesulitan itu terletak pada perbedaan watak bahasa asing dengan bahasa asli baik pada bunyi ataupun tulisan. Adapun penguasaan bahasa Arab sebagai bahasa asing kedua di sekolah khususnya untuk madarasah aliyah merupakan hal yang penting. Hal ini disebabkan sebagian pelajaran yang diberikan menggunakan bahasa Arab seperti pelajaran al-qura $>n$, al-hadi $>s \mid$, fiqh, aqidah akhlak. Oleh karena itu bahasa Arab merupakan pengetahuan dasar yang harus dikuasai oleh setiap siswa, karena bahasa menjadi alat untuk memelajari pelajaran agama selanjutnya.

Dalam proses pembelajaran akan selalu ada tiga aspek penting yang saling terkait satu sama lain. Tiga aspek itu adalah materi yang diajarkan, proses mengajarkan materi dan hasil dari proses pembelajaran tersebut. Banyak diantara

${ }^{1}$ Busyairi Madjidi, Penerapan Audio Lingual Method dalam all in one system. Yogyakarta : Sumbangsih Ofset, 1991. Hlm. 1 
para pengajar lebih memfokuskan pemikirannya pada materi dan hasil belajar. Waktu mereka tersita untuk menyiapkan rencana pembelajaran, serta perangkatperangkat pembelajaran lainnya. Namun ada satu hal yang perlu kita cermati, yaitu bagaimana mendesain proses pembelajaran, sehingga tujuan pembelajaran dapat tercapai

Berbicara tentang proses pembelajaran, selama ini bahasa arab diajarkan dengan metode yang dapat dikatakan masih konvensional. Artinya, proses belajar mengajar dilakukan dengan cara penyampaian materi, dilanjutkan dengan menghafal dan praktik, sehingga yang bekerja hanya lah otak kiri, dan ini bagi sebagian siswa terkesan monoton dan tidak menyenangkan. Tidak jarang pula demi mengejar target kurikulum, para pendidik membebani siswa dengan materi yang begitu banyak tanpa memperdulikan apakah siswa telah benar-benar faham, tertarik dengan yang diajarkan atau tidak. Padahal suasana belajar yang monoton akan menciptakan suasana yang tidak nyaman bahkan bisa membuat stress. Kondisi yang tidak kondusif ini akan sangat menyulitkan untuk meningkatkan minat belajar bahasa arab dan dapat mencapai hasil belajar yang optimal.

Dalam hal penggunaan media pembelajaran, selama ini dalam pembelajaran bahasa Arab media yang digunakan juga masih relatif sederhana, yaitu hanya menggunakan media buku pelajaran, papan tulis serta spidol. Para guru masih sering menemukan kesulitan dalam menyajikan materi pembelajaran kepada para siswa secara baik dan menarik, sehingga lebih mudah dipahami dan efektif dalam proses pembelajaran. Untuk itulah dibutuhkan suatu metode dan media pembelajaran bahasa arab yang sesuai, tepat dan menyenangkan, serta bisa memaksimalkan fungsi otak manusia dengan memadukan otak kanan dan otak kiri, sehingga pembelajaran bahasa arab dapat benar-benar tercapai tujuannya, memberi rasa senang bagi para siswa.

Proses pembelajaran merupakan proses penyampaian informasi atau proses komunikasi. Seringkali seorang guru mengalami kendala dalam melakukan komunikasi dalam proses pembelajaran. Oleh sebab itulah, maka dalam proses pembelajaran diperlukan alat bantu atau media untuk menyampaikan informasi. Mengingat keterbatasan yang dimiliki oleh alat bantu yang konvensional, maka sudah waktunya untuk para guru beralih menggunakan alat bantu yang dirancang oleh komputer. Penggunaan multimedia komputer dalam pembelajaran bahasa arab akan sangat membantu terhadap metodologi pengajaran bahasa arab sehingga guru dapat berperan sebagai fasilitator dalam proses pembelajaran. $^{2}$

2 Roestuyah NK, Strategi Belajar Mengajar, Salah satu Unsur Pelaksanaan Strategi Belajar Mengajar: Teknik Penyajian (Jakarta:Rineka Cipta, cet IV, Juli 1991), hlm 1. 
Melihat perkembangan pesat teknologi saat ini, dimana dunia teknologi telah masuk pada seluruh lini kehidupan manusia, mulai dari pekerjaan, pertemanan, hingga pada dunia pendidikan. Perkembangan teknologi dalam dunia pendidikan dapat kita jumpai pada menjamurnya e-learning, pembelajaran online dan lain sebagainya. Media komputer dimanfaatkan dalam pembelajaran karena memberikan keuntungan-keuntungan yang tidak dimiliki oleh media pembelajaran lainnya yaitu kemampuan komputer untuk berinteraksi secara individu dengan peserta didik.

Sementara itu, dalam pembelajaran bahasa arab buku teks yang ada masih sulit untuk dapat dipahami langsung oleh siswa. Kaidah-kaidah psikologi pembelajaran dan teori-teori desain suatu buku teks terkadang tidak teraplikasikan secara baik. Akibatnya siswa sulit memahami isi buku teks dan terkesan sering membosankan. Kita masih merasakan kurangnya software-software materi pembelajaran bahasa arab yang dikemas dalam bentuk $C D$, sehingga peserta didik dapat belajar lebih mandiri dan aktif.

Program Adobe Flash atau dulunya disebut Macromedia Flash tentu dapat menjadi tawaran pertama untuk memberikan solusi dari permasalahan diatas. Program Adobe Flash merupakan gabungan konsep pembelajaran dengan teknologi audiovisual yang mampu menghasilkan fitur-fitur baru yang dapat dimanfaatkan dalam pendidikan. Pembelajaran berbasis multimedia tentu dapat menyajikan materi pelajaran yang lebih menarik, tidak monoton, dan memudahkan penyampaian. Peserta didik dapat mempelajari materi pelajaran tertentu secara mandiri dengan komputer yang dilengkapi program multimedia. Dapat kita katakan bahwasannya teknologi multimedia memiliki kelebihan antara lain lebih menarik, efektif dan para siswa dapat lebih aktif.

Berdasarkan pengamatan awal yang dilakukan di Madrasah Mu'allimaat Muhammadiyah Yogyakarta tingkat Aliyah, terdapat berbagai macam masalah dalam pembelajaran Bahasa Arab diantaranya 1) Kesulitan siswa dalam memahami buku teks pembelajaran Bahasa Arab, sehingga menimbulkan rasa jenuh dan bosan sehingga menyebabkan kurang tertariknya siswa untuk mendalami bahasa arab. 2) Penggunaan media pembelajaran bahasa arab sampai saat ini masih terbatas. Guru masih dominan menggunakan buku teks dan papan tulis dalam menjelaskan materi pembelajaran bahasa arab, ditambah metode ceramah yang masih dominan. ${ }^{3}$ 3) Belum tersedianya software pembelajaran Bahasa Arab untuk siswa tingkat Aliyah yang dikemas dalam bentuk CD yang bisa digunakan oleh guru dan siswa dalam proses pembelajaran Bahasa Arab. 4) Sarana yang dimiliki oleh sekolah belum dioptimalkan pemanfaatannya untuk menunjang pembelajaran Bahasa Arab, seperti laboratorium komputer yang hanya digunakan untuk pembelajaran Teknologi Informasi. ${ }^{4}$

\footnotetext{
${ }^{3}$ Hasil wawancara dengan bapak A'la Subki yang dilakukan pada tanggal 20 Feb 2011

${ }^{4}$ Hasil observasi yang dilkakukan pada tanggal 25 februari 2011
} 
Mencermati permasalahan yang dikemukakan di atas, peneliti mencoba mengembangkan media pembelajaran berupa $C D$ interaktif untuk mata pelajaran Bahasa Arab. CD interaktif ini diharapkan dapat membantu mengatasi permasalahan tersebut sehingga menghasilkan pembelajaran yang menarik dan dapat memberikan motivasi siswa dalam belajar. Pembelajaran melalui media ini juga dapat membantu guru dalam proses belajar mengajar dan juga memberikan kesempatan kepada siswa untuk belajar mandiri dan mengulang materi yang belum jelas. Pengembangan CD interaktif sebagai alat bantu atau media dalam pembelajaran diperlukan dengan tujuan agar siswa dapat lebih mudah untuk mencerna secara logis materi pelajaran yang diberikan serta pembelajaran dapat lebih bervariasi.

\section{Spesifikasi Produk yang Dikembangkan}

Produk yang diharapkan dalam penelitian dan pengembangan ini adalah software multimedia interaktif pembelajaran Bahasa Arab untuk siswa madrasah aliyah semester genap yang dikemas dalam bentuk $\mathrm{CD}$, dengan spesifikasi sebagai berikut:

1. CD pembelajaran bahasa Arab yang dikembangkan bersifat interaktif, sehingga siswa dapat terlibat secara aktif dalam pembelajaran. CD pembelajaran ini digunakan untuk pembelajaran individual, namun tidak menutup kemungkinan untuk pembelajaran klasikal yang dibantu dengan menggunakan LCD.

2. CD interaktif Pembelajaran bahasa Arab ini memuat tentang:

a. Pendahuluan yang meliputi penjelasan mengenai standar kompetensi dan kompetensi dasar. Petunjuk yang meliputi cara penggunaan, alat-alat yang dibutuhkan serta penggunaan tombol.

b. Materi pokok yang disajikan dalam CD Interaktif Pembelajaran bahasa Arab ini adalah materi pembelajaran bahasa Arab kelas X semester genap tercakup dalam dua tema pokok yaitu tentang hobi dan pekerjaan, dengan penggunaan struktur kalimat mubtada' khabar, buruful jarr dan buruful atfi.

c. Menu utama dalam CD Interkatif Pembelajaran Bahasa Arab ini mencakup tiga belas tombol utama pembelajaran yang terdiri dari lima tombol untuk tema hobi dan lima tombol untuk tema profesi atau pekerjaan, satu tombol untuk kamus bahasa Arab, satu tombol untuk lagu dan film bahasa Arab, dan terakhir tombol evaluasi pembelajaran bahasa arab yang dalam hal ini mengggunakan program quiz creator evaluasi.

3. Pengoperasian CD Interaktif ini membutuhkan komputer yang memiliki sepesifikasi perangkat keras (hardware) dan perangkat lunak (software) sebagai berikut:

a. Software yang digunakan dalam produk ini adalah :

1) Adobe Flash CS3 untuk pembuatan CD Interaktif.

2) Adobe audition digunakan untuk proses rekaman dan editing suara. 
b. Hardware yang diperlukan yaitu:

1) Monitor dengan resolusi $1024 \mathrm{X} 768$ pixel

2) Processor intel pentium IV atau versi terbaru

3) Speaker

4) Mouse

5) Keybord

6) Ram 256, CD Room

7) Kebutuhan memory hard disk $220 \mathrm{mb}$

\section{Asumsi Pengembangan}

Pengembangan media pembelajaran ini juga didasarkan pada asumsiasumsi berikut:

1. Semua siswa mampu mengoperasikan komputer dengan baik.

2. Sebagian besar guru mampu mengoperasikan komputer dengan baik sehingga membantu dalam penggunaan metode pembelajaran yang bervariasi.

3. Media yang dikembangkan adalah sebuah CD Interkatif Pembelajaran Bahasa Arab, yang sifatnya sederhana sehingga mudah untuk digunakan.

4. Sekolah memiliki laboratorium komputer dengan jumlah dan spesifikasi komputer yang memadai sehingga media ini dapat digunakan dalam pembelajaran.

\section{Metode Penelitian}

\section{Model dan Prosedur Pengembanga}

Penelitian ini menggunakan model penelitian dan pengembangan (research and development) yang berorientasi pada produk.

Model pengembangan dalam penelitian ini adalah model pengembangan Borg \& Gall. Borg dan Gall mengemukakan tahapan penelitian dan pengembangan adalah :

a. Melakukan penelitian pendahuluan dan pengumpulan informasi (kajian pustaka, pengamatan kelas, persiapan laporan tentang persoalan).

b. Melakukan perencanaan (pendefinisian keterampilan, perumusan tujuan, penentuan urutan pembelajaran dan uji kelayakan).

c. Mengembangkan bentuk produk awal (penyiapan materi pembelajaran, penyusunan buku pegangan dan perlengkapan evaluasi)

d. Melakukan premilinary field testing

e. Melakukan revisi terhadap produk utama (sesuai dengan saran-saran dari hasil premilinary field testing

f. Melakukan main field testing (dilakukan pada 5-15 sekolah dengan 30-100 subjek). Data kuantitatif tentang unjuk kerja pada subjek pada pra pelajaran dan pasca pelajaran dikumpulkan. Hasil dinilai sesuai dengan tujuan pembelajaran dan dibandingkan dengan data kelompok apabila memungkinkan. 
g. Melakukan revisi terhadap produk operasional (revisi produk berdasarkan saran-saran dari hasil main field testing.

h. Mendesiminasikan dan mengimplementasikan produk (membuat laporan mengenai produk pada pertemuan profesional dan dalam jurnal, bekerjasama dengan penerbit untuk melakukan distribusi secara komersial, membantu distribusi untuk memberikan kendali mutu).

Sembilan langkah tersebut dapat disederhanakan menjadi empat langkah penelitian yaitu perencanaan, pengembangan, uji lapangan dan diseminasi. ${ }^{5}$

Adapun model desain pembelajaran yang digunakan dalam penelitian ini mengacu pada model desain pembelajaran yang dikembangkan oleh Dick \& Carey.

\section{Analisis Kebutuhan}

Tahap analisis kebutuhan meliputi :

1. Studi pustaka yang dilakukan adalah mengumpulkan informasi dan mempelajari literatur mata pelajaran bahasa arab dan buku-buku penunjang pembelajaran bahasa Arab lainnya, media pembelajaran, kurikulum bahasa Arab Madrasah Aliyah, dan silabus pembelajaran Bahasa Arab.

2. Studi lapangan yang dilakukan dengan melihat secara langsung keadaan sekolah, kondisi siswa, proses pembelajaran bahasa Arab, potensi yang dimiliki sekolah yaitu sekolah memiliki laboratorium komputer dan fasilitas komputer yang memadai sehingga CD Interaktif Pembelajaran yang dikembangkan dapat digunakan dalam pembelajaran.

\section{Desain Pembelajaran} berikut :

Desain pembelajaran pada penelitian ini melalui lima tahapan sebagai

1. Menetapkan Materi Pokok.

2. Menuliskan Standar kompetensi.

3. Menuliskan Kompetensi dasar

4. Merumuskan Indikator Keberhasilan

5. Merumuskan evaluasi pembelajaran

\section{Pengembangan Produk}

Pengembangan produk adalah tahap produksi dari CD interaktif Pembelajaran Bahasa Arab dengan langkah-langkah sebagai berikut:

1. Membuat storyboard yang merupakan skenario yang menggambarkan isi yang terdapat di dalam setiap slide CD Interaktif yang dikembangkan.

2. Menyiapkan materi yang dijadikan bahan media pembelajaran.

5 Anik Ghufron, dkk, Panduan Penelitian dan Pengembangan, Bidang Pendidikan dan Pembelajaran, (Yogyakarta: Lembaga Penelitian UNY, 2007), hlm 10-13 
3. Memilih software yang digunakan.

4. Memproduksi bahan yang diperlukaan kedalam program Adobe Flash, kemudian disalin dalam bentuk CD untuk dapat divalidasi pada ahli media dan ahli materi.

\section{Validasi Produk}

Validasi produk yang dilakukan terhadap ahli materi dan ahli media, dilanjutkan dengan analisis data. Revisi produk berdasarkan penilaian ahli materi dan ahli media. Validasi ahli materi dan ahli media sesuai dengan bidangnya, dan penting dilakukan untuk mendapatkan penilaian bahwa produk yang dikembangkan layak untuk digunakan

\section{Respon Guru dan Siswa}

CD interaktif yang sudah di validasi oleh ahli media dan ahli materi, di tampilkan kepada guru dan siswa untuk dimintakan tanggapan terhadap CD Interaktif Pembelajaran Bahasa Arab yang dikembangkan. Penilaian guru dan siswa sangat penting dilakukan untuk melihat tingkat kelayakan dari produk yang dikembangkan.

\section{Produk CD Interaktif Pembelajaran Bahasa Arab}

Produk Akhir merupakan hasil akhir dari serangkaian pengembangan CD Interaktif Pembelajaran bahasa Arab.

\section{Subjek Penelitian}

Subjek penelitian dalam pengembangan CD Interaktif Pembelajaran Bahasa Arab ini adalah :

1. Guru Bahasa Arab Madrasah Mu'allimaat tingkat Aliyah Yogyakarta.

2. Siswa Madrasah Mu'allimaat Muhammadiyah Yogyakarta.

\section{Jenis Data}

Untuk mengetahui kualitas produk yang dikembangkan, maka diperlukan data kuantitatif berupa skor tanggapan tentang kualitas produk dari ahli media dan ahli materi, serta guru dan siswa. Skor penilaian tentang kualitas produk dari ahli media meliputi tentang aspek tampilan dan aspek pemrograman. Skor penilaian dari ahli materi meliputi aspek pembelajaran dan aspek materi. Skor penilaian dari guru dan siswa meliputi aspek pembelajaran, materi, tampilan dan pemrograman.

\section{Instrumen Pengumpul data}

Instrumen yang digunakan untuk mengumpulkan data pada penelitian ini berupa angket. Angket digunakan untuk mengumpulkan data-data kuantitatif. Data-data ini digunakan untuk mengetahui kelayakan produk yang dikembangkan. 
1. Angket untuk ahli media, digunakan untuk memperoleh data tentang aspek tampilan dan aspek pemrograman. Instrumen penelitian berupa angket berdasarkan kisi-kisi yang telah dikembangkan yaitu:

a. Aspek tampilan terdiri dari 13 indikator penilaian, yaitu: (1) desain slide,

(2) pemilihan warna pada tulisan, gambar dan bagan, (3) pemilihan background, (4) ukuran huruf, (5) pilihan button, (6) tampilan gambar, (7) penempatan button, (8) tata letak (lay out), (9) kecepatan animasi, (10) penempatan gambar, (11) kejelasan narasi, (12) komposisi dan kombinasi warna, dan (13) musik pendukung.

b. Aspek pemrograman terdiri dari 11 indikator penilaian, yaitu: (1) kemudahan penggunaan, (2) tingkat interaktivitas pengguna terhadap media, (3) kemudahan navigasi, (4) konsistensi button, (5) pengaturan animasi, (6) komposisi setiap slide, (7) kejelasan petunjuk penggunaan, (8) kemudahan memilih menu, (9) ketepatan penggunaan tombol, (10) efisiensi teks, dan (11) kualitas tampilan gambar.

c. Angket untuk ahli materi, digunakan untuk memperoleh data tentang aspek pembelajaran dan aspek materi. Instrumen penelitian berupa angket berdasarkan kisi-kisi yang telah dikembangkan yaitu: Aspek pembelajaran terdiri dari 12 indikator penilaian, yaitu: (1) kesesuaian materi dengan kompetensi dasar, (2) kesesuaian indikator dengan kompetensi dasar, (3) kesesuaian materi dengan indikator, (4) sistematika penyajian materi, (5) kejelasan petunjuk belajar, (6) kebenaran uraian materi, (7) kejelasan sasaran program, (8) pemilihan strategi belajar (belajar mandiri), (9) pemberian contoh-contoh dalam penyajian materi, (11) kegiatan belajar dapat memotivasi siswa, dan (12) pemberian umpan balik.

d. Aspek materi terdiri dari 11 indikator penilaian, yaitu (1) materi mudah dipahami, (2) kebenaran isi materi yang disajikan, (3) kejelasan uraian materi, (4) kesesuaian materi dengan siswa, (5) kesesuaian contoh dengan materi, (6) kesesuaian latihan dengan materi, (7) konsistensi penyajian, (8) penggunaan bahasa yang tepat dalam menjelaskan materi, (9) variasi bentuk soal, (10) tingkat kesulitan soal, dan (11) kesesuain gambar, bagan untuk memperjelas isi.

2. Angket untuk guru dan siswa

Angket ini diberikan kepada 2 orang guru Bahasa Arab dan 30 siswa untuk melihat respon yang diberikan dari produk CD Interaktif Pembelajaran bahasa Arab yang dikembangkan. Angket ini digunakan untuk memperoleh data tentang aspek pembelajaran, aspek isi atau materi, aspek tampilan dan aspek pemrograman. Instrumen penelitian berupa angket berdasarkan kisi-kisi yang telah dikembangkan yaitu:

a. Aspek pembelajaran terdiri dari 8 indikator penilaian, yaitu: (1) kesesuaian materi dengan kompetensi dasar, (2) kemudahan memahami materi, (3) 
pemberian latihan untuk memahami materi (4) keseimbangan materi dengan contoh yang diberikan, (5) pemilihan strategi belajar (belajar mandiri), (6) kejelasan petunjuk belajar, (7) pemberian motivasi, dan (8) keseimbangan materi dengan soal tes.

b. Aspek isi/materi terdiri dari 9 indikator penilaian yaitu: (1) kelayakan materi, (2) kesesuaian materi dengan siswa, (3) kejelasan materi, (4) penggunaan bahasa dalam menjelaskan materi, (5) ketepatan contoh-contoh untuk memperjelas materi, (6) kejelasan petunjuk mengerjakan tes. (7) pemberian evaluasi akhir, (8) variasi bentuk soal, dan (9) konsistensi penyajian.

c. Aspek tampilan terdiri dari 11 indikator penilaian, yaitu: (1) desain slide, (2) pemilihan background, (3) pemilihan warna pada tulisan, gambar dan bagan, (4) keterbacaan tulisan, baik materi, petunjuk soal, maupun bagan, (5) ukuran huruf, (6) tata letak (layout), (7) kecepatan animasi, (8) kejelasan narasi, (9) penempatan button, (10) tampilan gambar, dan (11) penggunaan musik.

d. Aspek pemrograman terdiri dari 7 indikator penilaian, yaitu: (1) kemudahan penggunaan, (2) kejelasan petunjuk penggunaan, (3) kemudahan memilih materi untuk dipelajari, (4) pengaturan animasi, (5) kemudahan navigasi, (6) komposisi setiap slide, dan (7) efisiensi gambar.

\section{Teknik Analisis Data}

Teknik analisis dalam penelitian ini menggunakan teknik deskriptif kuantitatif. Data yang diperoleh melalui angket dari ahli materi dan ahli media, guru dan siswa terhadap produk yang dikembangkan kemudian dianalisis.

\section{Deskripsi hasil Analisis kebutuhan}

Pengembangan CD Interaktif Pembelajaran bahasa Arab untuk siswa Madrasah Aliyah Kelas X diawali dengan analisis Kebutuhan yang disimpulkan setelah mendapat informasi tentang materi pelajaran, kondisi siswa, dan proses belajar-mengajar. Data yang diperoleh dari kegiatan pengumpulan informasi ini adalah:

1. Studi Pustaka, dari kegiatan ini diperoleh informasi bahwa kurikulum pembelajaran bahasa Arab madrasah aliyah mulai tahun pelajaran 2004/2005 menerapkan kurikulum berbasis kompetensi (KBK) dan mulai tahun pelajaran 2006/2007 menerapkan kurikulum tingkat satuan pendidikan (KTSP). Proses pembelajaran Bahasa Arab siswa kelas X Madrasah Aliyah yang berlangsung menggunakan beberapa literatur antara lain:

a. Buku Bahasa Arab untuk Madrasah Aliyah Kelas X karya Dr. Hidayat Penerbit Karya Toha Putra semarang (2009).

b. Panduan belajar siswa Madrasah Aliyah Al-Hakim, Bahasa Arab kelas X, penerbit percetakan CV. Gema Nusa Klaten.

c. Buku Karya Ali Jazm dan Mustofa Amin, An-Nahwu Wa $>$ d $\{$ ih Jilid 1 dan 2 (terjemahan Drs. Ismail), Mesir, $\mathrm{Da}>\mathrm{rul} \mathrm{Ma}{ }^{\mathrm{a}} \mathrm{>}>$ rif. 
2. Gambaran proses belajar-mengajar hasil dari diskusi dengan guru mata pelajaran bahasa arab bahwa guru menyadari siswa kurang berminat terhadap pelajaran bahasa Arab, dikarenakan pembelajaran bahasa arab susah untuk dipahami dan membosankan. Media yang digunakan dalam pembelajaran bahasa Arab juga masih terbatas, buku paket dan LKS menjadi media utama dalam pembelajaran.

3. Studi lapangan yang di lakukan melalui pengamatan langsung bahwa sekolah memiliki fasilitas belajar diantaranya laboratorium bahasa dan laboratorium komputer yang belum digunakan dan dimanfaatkan secara optimal untuk pembelajaran bahasa Arab. Dapat disimpulkan bahwa pengembangan multimedia berupa CD interaktif pembelajaran bahasa Arab untuk siswa madrasah Aliyah sangat diperlukan.

CD Interaktif pembelajaran bahasa Arab siswa untuk siswa madrasah aliyah di kembangkan berdasarkan pada analisis kebutuhan yang disimpulkan setelah mendapatkan berbagai informasi diantaranya bahwa media untuk pembelajaran bahasa Arab sangat terbatas, sehingga software-software pembelajaran bahasa Arab sangat di butuhkan dalam pembelajaran.

\section{Deskripsi Desain Pembelajaran}

Dari hasil studi lapangan dan studi pustaka, dapat disusun sebuah Desain Pembelajaran. Desain pembelajaran pada penelitian ini melalui lima tahap yaitu: 1. Menetapkan materi pokok.

Melalui wawancara dan saran dari guru bahasa Arab Madrasah Mu'allimaat Muhammadiyah Yogyakarta materi-materi yang akan digunakan dalam CD Interaktif ini yaitu materi-materi pembelajaran bahasa arab untuk siswa madrasah Aliyah kelas X semester genap yaitu tentang al-hiwa $>$ yah dan almih\}natu. Materi-materi tersebut mencakup empat kemahiran bahasa yaitu menyimak, berbicara, membaca, dan menulis, dengan struktur kalimat mubtada' khabar, buruful jarr dan buruful atfi.

2. Menetapkan Standar Kompetensi.Standar kompetensi yang dijadikan acuan adalah:

a. Menyimak .Memahami informasi lisan berbentuk paparan atau dialog tentang hobi dan pekerjaan.

b. Berbicara. Mengungkapkan informasi secara lisan berbentuk paparan atau dialog tentang hobi dan pekerjaan.

c. Membaca .Memahami wacana tertulis berbentuk paparan atau dialog tentang hobi dan pekerjaan.

d. Menulis .Mengungkapkan informasi secara tertulis berbentuk paparan atau dialog tentang hobi dan pekerjaan.

3. Menuliskan Kompetensi Dasar.

a. Menyimak 
b. Berbicara

1) Mengidentifikasi bunyi, ujaran (kata, frasa atau kalimat) dalam suatu konteks dengan tepat tentang hobi dan pekerjaan

2) Menangkap makna dan gagasan atau ide dari berbagai bentuk wacana lisan secara tepat tentang hobi dan pekerjaan.

1) Menyampaikan gagasan atau pendapat secara lisan dengan lafal yang tepat tentang hobi dan pekerjaan

2) Melakukan dialog sesuai konteks dengan tepat dan lancar tentang hobi dan pekerjaan.

c. Membaca

1) Mengidentifikasi bentuk dan tema wacana secara tepat dan benar tentang hobi dan pekerjaan

2) Menemukan makna dan gagasan atau ide wacana tulis secara tepat tentang hobi dan pekerjaan.

d. Menulis

1) Menulis kata, frasa, dan kalimat dengan huruf, ejaan dan tanda baca yang tepat dan benar tentang hobi dan pekerjaan.

2) Mengungkapkan gagasan atau pendapat secara tertulis dalam kalimat dengan menggunakan kata, frasa, dan struktur yang benar tentang hobi dan pekerjaan.

\section{Deskripsi Pengembangan Produk Awal}

Proses produksi CD Interaktif Pembelajaran ini diolah dalam program Adobe Flash CS3 dan program-program pendukung lainnya seperti Adobe Audition untuk rekaman. Proses produksi tersebut dapat berjalan dengan baik serta berdasarkan pada rangcangan story board yang sudah dibuat sebelumnya dan kesiapan bahan-bahan yang diperlukan.Secara garis besar rancangan produk awal CD Interaktif pembelajaran Bahasa Arab yaitu:

1. Halaman pembuka berisi nama produk, dan satu tombol untuk melanjutkan.

2. Halaman kedua berisi 3 tombol utama yaitu : al-muqaddimah, al-irsyadat dan al-qa'imah ar-raisyah. Untuk al-muqaddimah atau pendahuluan terdiri dari tiga tombol berisi standar kompetensi dan kompetensi dasar. al-irsyadat atau petunjuk terdiri dari 2 tombol yang berisi cara penggunaan, dan perangkat yang dibutuhkan. Sedangkan al-qa'imah ar-raisyah atau menu utama terdiri dari 13 tombol menu utama CD Interaktif pembelajaran Bahasa Arab. Adapun penjelasan dari masing-masing tombol sebagai berikut:

a. Al-Istima' 1 (menyimak) berisi materi tentang al-biwayah, terdiri dari dari 8 tombol, masing-masing tombol berisi, Istima' 1 , Istima' 2, tadribat 1, tadribat 2, al-istima 3, tadribat 3, 4, dan 5 .

b. Al-Hiwar (dialog) berisi materi dialog tentang al-biwayah. 
c. Al-Qiro'ah 1 (membaca) berisi bacaan tentang al-biwayah, terdiri dari 8 tombol yang berisi tentang qiro 'ah, tadribat 1,2,3,4,5,6.

d. Al-Kitabah 1 (menulis) berisi materi tentang tanda baca dalam bahasa Arab (alamatu at-tarqimi), al-misal, tadribat 1,2,3.

e. Qawa'id, berisi materi tentang qaidah-qaidah nabwu dan saraf terdiri dari 11 tombol yang berisi materi saraf tentang masdar fi'lu sulasi, masdar fi 'lu ruba' $i$, dan ditambah tadribat, kemudian tombol berikutnya berisi materi nabwu tentang mubtada' khabar beserta tadribat.

f. Istima'2 (menyimak) berisi materi tentang al-mibnatu terdiri dari 7 tombol. Berisi tentang materi Istima' untuk tema al-mihnatu dan di tambah beberapa tadribat.

g. Al-hiwar 2 (dialog) berisi materi dialog tentang al-mibnatu.

h. Al-Qiro'ah 2 (membaca) berisi bacaan tentang al-mibnatu, terdiri dari 8 tombol .

i. Al-Kitabah 2 (menulis) terdiri dari 3 tombol.

j. Qawa 'id 2, berisi qa 'idah nabwu tentang hurufu jarr dan huruf atf.

k. Qamus, yang mencakup kosa-kata tentang al-biwayah dan al-mibnatu.

1. Agani berisi lagu-lagu dan film.

m. At-taqwimi atau evaluasi, dalam CD Interaktif Ini Evaluasi terdiri dari 2 tema, yaitu evaluasi untuk tema al-biwayah dan al-mibnatu yang terdiri dari bentuk pilihan ganda dan mencocokkan. Evaluasi ini menggunakan program quiz. creator yang nantinya di publish kedalam flash player.

Secara garis besar pembuatan CD Interaktif Pembelajaran bahasa Arab untuk siswa madrasah aliyah ini dengan menggunakan program Adobe Flash CS3 menggunakan langkah-langkah sebagai berikut:

1. Menginstal program adobe flash ke dalam komputer.

2. Membuka program Adobe flash CS3, dengan langkah-langkah sebagai berikut:

a. Klik tombol start pada windows taskbar.

b. Klik menu All Programs > Adobe Flash CS3, setelah itu akan tampil jendela program Adobe Flash dan halaman start.

c. Pada halaman start klik bagian Create New $>$ action script 0,2 untuk membuka dokumen baru.

d. Selanjutnya mengubah ukuran stage dengan mengklik windows $>$ properties, pada size ubah ukuran 800 X600 px.

e. Untuk mengetahui warna background color, klik tombol warna pada background lalu pilih warna biru.

f. Untuk frame rate ganti dengan $30 \mathrm{fps.}$

3. Penullis membuat ruang untuk mendesain CD Interaktif Pembelajaran bahasa Arab dengan cara membuat 4 layer dasar yaitu layer background, layer materi, layer tombol dan layer action. Adapun langkah-langkahnya adalah sebagai berikut: 
a. Tambahkan layer baru, masing-masing diberi nama background, materi, tombol dan action.

b. Pada layer background, membuat objek kotak dengan cara mengklik rectangle tool.

c. Pada layer materi, membuat blank key frame dengan cara memilih frame 20 klik kanan lalu pilih insert blank key frame, begitu juga pada frame 40,60,80 dan 100.

d. Pada layer action, peneliti menambahkan action script dengan cara mengklik f9 lalu klik script stop ();

4. Membuat tombol sebagai link perpindahan halaman antar materi, dengan langkah-langkah sebagai berikut:

a. Pilih layer tombol, pada sorot frame 1, kemudian membuat sebuah objek elips dengan menggunakan rectange tool caranya pilih rectange tool pada tool box, pada properti dibawah isi nilai pada rectange corner radius: 50, pilih objek elips dan diberi warna biru.

b. Memilih objek $>$ modify $>$ convert to symbol atau klik kanan objek $>$ pilih convert to symbol, setting pada dialog $>$ nama: button, type : button, lalu klik ok.

c. Memberikan efek pada tombol dengan cara mengklik kanan pada objek tombol > pilih edit/double klik pada tombol, saat kita mengedit sebuah tombol, kita akan di bawah ke ruangan button dengan timeline yang berbeda. Klik kanan pada frame over $>$ pilih insert key frame, maka pada frame akan ditandai dengan titik hitam, berarti pada frame terdapat objek baru, pilih objek, lalu kita rubah warnanya dengan warna hijau. Selanjutnya klik kanan pada frame down $>$ pilih insert keyframe $>$ pilih objek dengan memberi warna merah.

d. Masih pada ruang button, selanjutnya membuat layer baru lalu insert keyframe pada Up dan kita buat teks tulisan dengan cara mengklik text tool, lalu diposisikan diatas tombol yang telah kita buat.

e. Langkah terakhir adalah memfungsikan tombol yang telah kita buat dengan cara menambahkan action script. Adapun script yang digunakan untuk memberi fungsi tombol adalah:

On (release) (goto AndStop (1);)

Angka satu merupakan halaman yang akan dituju oleh tombol yang kita buat, sehingga tombol akan memiliki halaman yang berbeda-beda sesuai link yang diinginkan.

5. Mengisi materi pelajaran pada layer materi yang telah dibuat, adapun langkah-langkahnya sebagai berikut:

a. Memilih layer materi frame 1, kemudian klik text tool dan klik area kosong pada stage yang ada dan drag seperlunya sesuai dengan materi yang akan dimasukkan.

b. Mengklik kontrol f3 lalu pada properties mengubah bentuk tulisan menjadi dynamic text, font arial arabic, color hitam. Pada program adobe flash tulisan 
Arab hanya dapat ditulis dengan bentuk dynamic text, kalau kita menggunakan static text maka hurufnya akan terputus. Namun apabila kita mengetik menggunakan huruf latin maka bentuk tulisan dapat memilih static text.

c. Selanjutnya penulis memulai untuk menulis materi pelajaran. Setelah menyelesaikan satu materi, untuk dapat menulis materi selanjutnya maka materi pertama dijadikan movie clip untuk membuka ruang menambah selanjutnya. Caranya adalah dengan mengklik kanan materi yang telah ditulis, pilih convert to symbol, lalu setting pada dialog $>$ nama materi 1, type Movie Clip lalu klik OK.

d. Pada ruangan yang baru penulis menambahkan materi-materi lainnya.

e. Setelah selesai kembali ke scane 1, untuk selanjutnya mengulangi memasukkan materi lainnya ke dalam ruang yang disesain sebelumnya.

6. Memasukkan gambar dan video ke program flash. Adapun langkahlangkahnya adalah:

a. Untuk mengimport gambar ke stage dengan cara mengklik file $>$ import $>$ import to stage, setelah itu akan tampil kotak dialog import. Kemudian memilih gambar yang akan diimport lalu klik open. Hasilnya gambar akan tampil di area stage.

b. Untuk mengimport video, dilakukan dengan cara mengklik file $>$ import $>$ import video. Setelah itu kotak dialog import video akan tampil. Kemudian mengklik tombol browse lalu memilih file video, kemudian mengklik tombol open. Kemudian mengklik tombol next lalu memilih Embed video in SWF dan play in timeline, klik next untuk skinning pilih StellOver All.swf, klik tombol next lalu pilih tombol finish.

Langkah-langkah tersebut diatas merupakan langkah dasar mendesain pembelajaran berbasis komputer dengan menggunakan software adobe flash CS3

\section{Validasi Ahli Media}

Ahli media yang menjadi validator dalam produk penelitian ini adalah ibu Kuswari Hernawati, M.Kom, dosen Universitas Negeri Yogyakarta yang memvalidasi CD Interaktif Pembelajaran bahasa Arab dari aspek tampilan, dan Bapak Nur Hadi, M.Eng dosen Universitas Negeri Yogyakarta yang memvalidasi CD Interaktif Pembelajaran bahasa arab dari aspek pemrograman. Data diperoleh dengan cara memberikan angket aspek pemrograman dan aspek tampilan. Data yang berupa penilaian dan saran digunakan untuk memperbaiki produk CD Interaktif Pembelajaran bahasa Arab yang dikembangkan.

Menurut ahli media produk yang dikembangkan secara keseluruhan sudah bagus dan layak untuk digunakan dengan revisi sesuai yang disarankan. Ada beberapa perbaikan dari produk awal hasil dari validasi ahli media diantaranya adalah: 
1. Petunjuk penggunaan tidak jelas pada tiap-tiap slide.

2. Perbaikan ukuran huruf.

3. Desain slide diperbesar.

4. Untuk pemilihan background pada masing-masing slide perlu diperhatikan dan dirubah.

5. Musik pengiring harus diperhatikan dan ada tombol on / offnya.

Hasil validasi ahli media terhadap CD Interkatif Pembelajaran Bahasa Arab menunjukkan bahwa:

1. Aspek tampilan. Berdasarkan Tabel 3 diketahui bahwa hasil penilaian pada aspek tampilan dengan rerata 4,15. Berdasarkan konversi data kuantitatif ke data kualitatif skala 5 (tabel 2) termasuk kategori "baik".

2. Aspek pemrograman. Berdasarkan tabel 4 diketahui bahwa penilaian ahli media pada aspek pemrograman dengan rerata 4,00. Berdasarkan konversi data kuantitatif ke data kualitatif skala 5 (tabel 2) termasuk kategori "baik".

\section{Deskripsi Validasi Ahli Materi}

Ahli materi dalam hal ini adalah Drs. A'la Subki, salah satu guru bahasa Arab tingkat Aliyah Madrasah Mu'allimaat Muhammadiyah Yogyakarta. Validasi materi dilakukan sebelum materi di olah didalam software dan sesudah materi diolah kedalam software Adobe Flash CS 3. Penilaian ahli materi terhadap produk media pembelajaran hasil pengembangan dari dua aspek, yaitu aspek pembelajaran dan aspek isi/materi. Data ini diperoleh dengan cara memberikan angket aspek pembelajaran dan aspek isi/materi. Secara umum produk CD Interaktif Pembelajaran Bahasa Arab yang dikembangkan ini sudah bagus, baik konsep dan susunannya, tapi ada beberapa yang perlu diperhatikan baik dari aspek pembelajaran maupun aspek isi/materi, antara lain:

1. Harus lebih teliti dalam penulisan, yang berkenaan dengan harakat dan tata bahasa.

2. Harus teliti dalam penulisan, yang berkenaan dengan latihan-latihan soal atau tadribat.

3. Kejelasan petunjuk belajar pada masing-masing materi Materi.

Adapun Validasi CD Interaktif Pembelajaran Bahasa Arab oleh Ahli

1. Aspek pembelajaran. Berdasarkan pada tabel 5 diketahui bahwa penilaian ahli materi pada aspek pembelajaran dengan rerata 4,17. Menurut tabel konversi data kuantitatif ke data kualitatif skala 5 (tabel 2) termasuk kategori "baik".

2. Aspek isi/materi. Berdasarkan pada tabel 6 diketahui bahwa penilaian ahli materi pada aspek isi/materi dengan rerata 4,00. Berdasarkan tabel konversi data kuantitatif ke data kualitatif skala 5 (tabel 2) termasuk kategori "baik". 


\section{Daftar Kepustakaan}

Anik Ghufron, dkk (2007), Panduan Penelitian dan Pengembangan, Bidang Pendidikan dan Pembelajaran. Y ogyakarta: Lembaga Penelitian UNY

Arif S. Sadiman, dkk. (2006). Media Pendidikan: Pengertian, Pengembangan, dan Pemanfaatannya. Jakarta : Raja Grafindo Persada.

Asri Budiningsih, C. (2005). Belajar dan Pembelajaran. Yogyakarta : Rineka Cipta

Azhar Arsyad. (2007). Media Pembelajaran. Jakarta: Raja Grafindo Persada.

- (2002) Bahasa Arab dan Metode Pengajarannya, Jakarta : Raja grafindo Persada

Baharudin \& Esa Nur Wahyuni. (2008). Teori Belajar dan pembelajaran. Yogyakarta: Ar-Ruzz Media.

Brog, Walter R \& Gall Meeredit D. (1983). Educational Research: An Introduction (4 ed). New York : Longman Inc.

Busyairi Madjidi. (1994). Penerapan Audio Lingual method dalam all in one system. Yogyakarta : Sumbangsih Offset.

Desmita, (2009). Psikology Perkembangan Peserta Didik. Bandung : Rosda.

E Mulyasa, Kurikulum Tingkat Satuan Pendidikan, Bandung : PT Remaja Rosda Karya

Fathul Mujib, (2010), Rekonstruksi Pendidikan Bahasa Arab dari Pendekatan Konvensional ke Integratif Humanis, Yogyakarta : Pedagogia

Fuad Effendi, 2005, Metodologi Pengajaran Bahasa Arab, cet. III, Malang : Misykat.

Giam Kah How, (2010), Gaya Pembelajaran dan Penggunaan Multimedia dalam Pengajaran Pembelajaran. Jurnal Pendidikan Tigaef jilid 2 : bil 3

Heinich, et al. (1996). Instructional Media and technologies for Learning (5 th ed). New jersey : Prentice Hall ins.

Imam Ma'ruf, Strategi Pembelajaran Bahasa Arab Aktif. Semarang : Need's Press

Kemp, J.E. \& Dauton, D.K. (1985), Planning and Producing Instructuinal Media(5 th ed). New York : Harper \& Row, Publisher.

M. Abdul Hamid, dkk, Pembelajaran bahasa Arab, Pendekatan, Metode, Strategi, materi dan Media. Malang: UIN Malang Press.

Multimedia. Yogyakarta : Universitas Negeri Yogyakarta Press

Radliyah Zaenudin, dkk. (2005), metodologi dan Strategi Alternatif Pembelajaran Bahasa Arab. Yogyakarta: Rihlah Group.

Richard E Mayer, (2009), Multimedia Learning, Prinsip-Prinsip Aplikasi. Yogyakarta: Pustaka Pelajar

Suyanto, (2003). Multimedia Alat untuk Meningkatkan Keunggulan bersaing. Yogyakarta: Andi Offset

Umi Mahmudah \& Abdul Wahab Rosyidi, (2008), Active Learning dalam Pembelajaran bahasa Arab. Malang: UIN. Malang Press

Wacana Prima, (2008), Media Pembelajaran. Bandung: CV Wacana Prima.

Yudhi Munadhi. (2008), Media Pembelajaran Sebuab Pendekatan Baru. Jakarta: Gaung Persada Press 